\title{
Geological setting and genesis of stratabound barite deposits at Múzquiz, Coahuila in northeastern Mexico
}

Francisco González-Sánchez ${ }^{a, *}$, Eduardo González-Partida ${ }^{b}$, Carles Canet ${ }^{c}$, Viorel Atudorei ${ }^{\text {, }}$ Pura

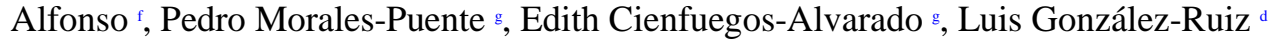

${ }^{a}$ Instituto Tecnológico Superior de Tacámbaro, Av. Tecnológico 201, Zona El Gigante, 61650 Tacámbaro, Michoacán, Mexico

${ }^{b}$ Centro de Geociencias, Universidad Nacional Autónoma de México, Boulevard Juriquilla 3001,76230 Juriquilla, Querétaro, Mexico

${ }^{c}$ Instituto de Geofísica, Universidad Nacional Autónoma de México, Ciudad Universitaria, 04510 México, D.F., Mexico

${ }^{d}$ Geologia Minería y Consultoría, Av. Zaragoza 332-A int 51, Col. Niños Heroes, CP 76010 Santiago de Querétaro, Querétaro, Mexico

e Department of Earth and Planetary Sciences, The University of New Mexico, Northrop Hall, Albuquerque, NM 87131, USA

${ }^{f}$ Departament d'Enginyeria Minera i Recursos Naturals, Universitat Politècnica de Catalunya, Av. de les Bases de Manresa 61-73, 08242 Manresa, Catalonia, Spain

${ }^{g}$ Instituto de Geología, Universidad Nacional Autónoma de México, Ciudad Universitaria, 04510 México, D.F, Mexico

* corresponding author: camprubitaga@gmail.com 


\section{ABSTRACT}

The opening of the Gulf ofMexico during the Mesozoic led to the formation of the Sabinas Basin. Large carbonate platformswere developed throughout the Lower andMiddle Cretaceous. The basin provided ideal conditions for the formation of a suite of carbonatehosted, stratabound deposits such as barite, celestine, fluorite, and lead-zinc of BarremianAptian age. These deposits resemble Mississippi Valley-type (MVT) and associated deposits. The mining district of Sierra de Santa Rosa is located approximately $\sim 7 \mathrm{~km} \mathrm{SE}$ from Melchor Múzquiz in the state of Coahuila, Mexico. Barite is the economic mineral and the shape of the ore bodies is considered "mantos", the gangue minerals are calcite, local gypsum, traces of celestine, silica, and iron (oxy) hydroxides. The barite deposits show relict textures such as rhythmic, alternating black and white bands due to the presence of organic matter, and globular clusters similar to the "chicken-wire" anhydrite, typical of evaporites. A fluid inclusion and stable isotope analysis ( $\mathrm{S}$ frombarite, $\mathrm{C}$ and $\mathrm{O}$ from carbonates) were conducted. The lower manto yielded a melting ice temperature between $-26{ }^{\circ} \mathrm{C}$ and $-5{ }^{\circ} \mathrm{C}$ (salinities of 7.9 to 27 wt.\% $\mathrm{NaCl}$ equiv.) and a homogenization temperature ranged between $59^{\circ} \mathrm{C}$ to $155^{\circ} \mathrm{C}$. The eutectic temperature was $-51{ }^{\circ} \mathrm{C} \pm 2{ }^{\circ} \mathrm{C}$ denoting a primary calcic brine. The upper manto yielded a melting ice temperature between-22 ${ }^{\circ} \mathrm{C}$ and $-15{ }^{\circ} \mathrm{C}$ (salinities of 18.6 and 24 wt.\% $\mathrm{NaCl}$ equiv.) and a homogenization temperature was ranging from $60{ }^{\circ} \mathrm{C}$ to $126^{\circ} \mathrm{C}$. Isotopic analysis of barite showed $\delta^{34} \mathrm{~S}_{\mathrm{VCDT}}$ ranges from $+14.9 \%$ to $+19.5 \%$ (average of $16.9 \%$ ). Sulfur isotope data for barite from the Sierra de Santa Rosa is consistent with a sulfur source formed during the Lower Cretaceous, which coincides with the age of the Cupido Formation. The carbon isotope analysis of the host limestone yielded a $\delta^{13}$ CVPDB range from $-0.01 \%$ to $+0.11 \%$. The $\delta^{13} \mathrm{C}$ values for clear and gray calcites ranged from $-0.15 \%$ to $-1.5 \%$, and $-1.41 \%$ oto $-2.3 \%$, respectively. The oxygen isotope analysis showed a range between $\delta^{18} \mathrm{O}_{\text {VSMOW }}-4.55 \%$ and-10.04\%o. Fluid inclusionmicrothermometry and isotopic measurements lead us to conclude that brines fromthe Sabinas Basin led to the replacement of the evaporite strata (gypsum) by barite in the Cupido Formation and thus classify these deposits within the category of MVT and associated deposits. 


\section{Introduction}

The sedimentary-diagenetic domain of northeastern Mexico are: 1) sedimentaryexhalative or SEDEX deposits, like the manganese Molango deposit in Hidalgo, (Zantop, 1978; Alexandri and Martínez, 1986; Okita, 1992); 2) Mississippi Valley-type and associated deposits of: fluorite, such as La Sabina and El Tule in Coahuila and Las Cuevas in San Luis Potosí; celestine, such as La Tinaja and San Agustin in Coahuila (GonzálezSánchez et al. 2007); barite, such as La Paila, and Mayran in Coahuila and La Huicha in Nuevo Leon (Clark and De la Fuente, 1978; Kesler and Jones, 1981; Puente-Solís, et al., 2005; Camprubí, 2009, 2013); Zn-Pb sulfides, such as Sierra Mojada and Reforma in Coahuila and El Diente in Nuevo Leon; 3) $\mathrm{Cu}-\mathrm{Co}$ deposits; such as, El Huizachal in Tamaulipas, San Marcos in Coahuila, and El Coyote and Las Vigas in Chihuahua, (Clark and De la Fuente, 1978); and 4) U deposits in detrital sequences, or Kupferschiefer-type "red beds"; such as, Sierra de Gómez in Chihuahua, and El Nopal, Las Margaritas, La Coma and Buenavista in Tamaulipas. With the exception of the SEDEX deposit, which is largely syngenetic, these deposits are epigenetic and occur in basins of Mesozoic-Cenozoic age associated with the opening of the Gulf of Mexico, with themajority of themin the states of Coahuila and Chihuahua (Fig. 1). Actually there are some comprehensive reviews such as (González-Sánchez et al., 2007, 2009; Caballero-Martínez and Sánchez-Rojas, 2011; and Camprubí, 2009, 2013). None of these deposits have been properly dated and age estimations are only available for the SEDEX deposit, the stratigraphic correlation suggests a relative age for these deposits that ranges from Oxfordian to Kimmeridgian (?), (SotoPineda, 1960; Imlay, 1937; Vivanco-Flores, 1976; and Okita, 1992). Despite the lack of geochronological determinations for the sedimentary-diagenetic deposits, and according to González-Sánchez et al. (2007, 2009), we may, nevertheless, speculate about a tentative timing for the deposition of MVT and clastic sediment-hosted ore deposits relative to the orogenic pulses in the region, suggesting a possible pre-Sevier, syn-Sevier, syn-Laramide and post-Laramide deposits.

Among the mineralized basins, the one that presents the clearest regional anatomy is the Sabinas basin in Coahuila, for which González- Sánchez et al. (2007, 2009) and GarcíaAlonso et al. (2011) determined the preferential distribution of the differentmineralogical 
types of MVT and associated deposits and 'red-bed' deposits as follows: 1) $\mathrm{Pb}-\mathrm{Zn}$ and barite occur deep in the basin or close to the San Marcos Fault, the southernmost main fault delimiting the basin, and are formed from the hottest and most saline mineralizing brines in the region; 2) celestine and fluorite deposits occur on the margins of the basin near the San Marcos and La Babia Faults, the southernmost and northernmost main faults in the region, in shallow stratigraphic sections and are associated with dilute and relatively cool fluids; and 3) $\mathrm{Cu}-\mathrm{Co}-\mathrm{Ni}-\mathrm{Zn}$ red-bed deposits occur in clastic formations along the main faults as the products of deposition from highly saline and relatively cool brines.

The barite deposits atMúzquiz constitute the paramount example of the first category ofMVT-like deposits in this region. Thismining district is located in the Santa Rosa Range, about $7 \mathrm{~km}$ southeast of Múzquiz in the central part of Coahuila. The barite deposits have been mined since 1936 and historically are the third largest barite producer in the country. A fairly steady monthly production of $4000 \mathrm{t}$ of barite concentrate has been delivered since the 1980s by the mining company, Barita de Santa Rosa (BAROSA), out of the mineralized mantos hosted in the Lower Cretaceous Cupido Formation. The barite ores are present along a $20 \mathrm{~km}$ NW-striking mineralized area on the northeastern flank of the Santa Rosa Range. They are banded stratabound bodies composed of high-purity barite and smaller, non-economic ore bodies of $\mathrm{Pb}-\mathrm{Zn}$ in the upper levels of the barite deposits at the base of the Georgetown Formation (González-Sánchez et al., 2009) with karstic voids and fractures filled by $\mathrm{Pb}-\mathrm{Zn}$ sulfides (González-Sánchez, 2008).

Geological, microthermometric, and isotopic data provided in this paper are focused on defining the genesis of the stratabound barite deposits of Múzquiz, Coahuila, Mexico.

\section{Geology}

The structural and paleogeographic features of northeasternMexico during theMesozoicwere determined by threemajor geological events. First, the opening of the Gulf of Mexico due to extension related to the breakup of Pangea and the rifting-apart of the Yucatán Block in a southward direction, wherein it reached its approximate present position by the Middle of the Jurassic (Marton and Buffler, 1994; Pindell and Kennan, 2001) and provoked the subsequent formation of several sedimentary basins. This event 
determined the formation and architecture of the Sabinas Basin, among others. Second, the development of broad sedimentary platforms on raised blocks between the Lower and the Middle Cretaceous, which was responsible for formation of lithological units of carbonate and local evaporites (Enos, 1974, 1983; Wilson, 1975; Smith, 1981; Goldhammer and Johnson, 2001). Third, the subduction processes from the Paleo-Pacific margin and the Laramide orogeny associated with them eventually extended into this region, especially during the Cenozoic (Camprubí, 2009, 2013). Despite the concomitance of various types of magmatic-hydrothermal ore deposits with such processes, there is no relationship between these and the deposits identified as MVT or red-bed-type deposits by González-Sánchez et al. (2007, 2009). The Sabinas Basin was bound by the Coahuila paleoisland to the south across the San Marcos Fault, the Burro-Peyotes paleo-peninsula to the north and east across the La Babia Fault, and the Tamaulipas paleo-archipelago to the east and was connected to some degree with the Chihuahua Basin to the west and the La Popa Basin to the southeast.

Such positive and negative paleo-geographic featureswere limited by normal faults in a horst-and-graben arrangement. These features controlled sedimentation (Padilla Y Sánchez, 1986), and would also eventually control the emplacement of sedimentary brines into shallower portions of the stratigraphic section, wherein the formation of MVT and red-bed deposits occurred (González-Sánchez et al., 2007, 2009; García-Alonso et al., 2011). Between the Triassic and the Middle of the Jurassic, thick sequences of lacustrine, evaporitic, alluvial-fan red-beds and other clastic sediments were deposited in the Sabinas Basin (Padilla Y Sánchez, 1986; Lehmann et al., 1999) under a regime of subsidence associated with the opening of the Gulf of Mexico (Goldhammer and Johnson, 2001). Carbonate platforms on top of the Paleozoic to Triassic basement rocks (horsts) did not form until the Aptian-Albian.

The oldest rocks in the Múzquiz area, (Fig. 2), correspond to the HauterivianBarremian La Virgen Formation, which comprises intercalations of limestone, shale, and evaporite horizons (Imlay, 1940). The La Virgen Formation is overlain by the $740 \mathrm{~m}$ thick Barremian-Aptian Cupido Formation (Imlay, 1937), which consists of generally thickbedded limestone and a reef facies abundantly distributed throughout northeastern Mexico. Occurrences of this formation on the Coahuila paleo-island display several changes of facies (Lehmann et al., 1999), mainly a shelfmargin facies to the northwest, a 
high-energy grainstone facies in the south, and a discontinuous coral-rudist reef facies to the east, facing the ancestral Gulf of Mexico.

The Cupido Formation is overlain by the late Aptian La Peña Formation, which consists of thinly bedded shales with abundant fauna, especially ammonites. This formation, $20 \mathrm{~m}$ thick in theMúzquiz area, is also broadly distributed in northeastern Mexico and consists of homogeneous platform facies, with pelagic and shallow terrigenous sediments. It is in turn overlain by the early Albian Aurora Formation, which consists of thickly bedded limestone that formed in quiet shallow platform environments (Humphrey, 1956) and is 662mthick in the study area. This is overlain by theMid-Albian Kiamichi Formation, which constituted of thinly bedded limestone intercalated with clay-rich horizons that formed in platform environments under the influence of the open sea, and is $75 \mathrm{~m}$ thick. The above sedimentary lithological sequence was discordantly covered by Quaternary basalts. At the base of basalt unit, there are barite fragments, such as xenoliths, which were dragged from the barite deposits (Torres-Hernández, 2003).

\section{Mineralization}

The barite deposits consist of mantos that have a stratabound and epigenetic character. They are emplaced in limestone in the upper part of the Cupido Formation close to the contact with the La Peña Formation. These ore deposits are not associatedwith a magmatic or volcanic event and showno evidence ofmetamorphism. The host rock shows a halo of dolomitization alteration type and its formation is related to an orogenic event.

There are twomain orebodies, locally known as the upper and lower mantos. Each is up to $20 \mathrm{~km}$ long, 1 to $5 \mathrm{~m}$ in thickness (averaging $2.5 \mathrm{~m}$ ), with a general $69^{\circ} \mathrm{NW}$ strike and dip of $0^{\circ}$ to $30^{\circ} \mathrm{NE}$. The two orebodies are separated fromone another by $30 \mathrm{~m}$, and also are located $30 \mathrm{~m}$ below the La Peña Formation. The potential for undiscovered extensions of both as well as other possible mantos is large since most of the Cupido Formation in the area does not outcrop at the surface.

Ore mineralogy is nearly pure barite and the gangue minerals are mainly patches of coarse calcite and trace amounts of celestine, scarce amorphous silica, Fe-(oxy) hydroxides, and Mn-oxides. The presence of brecciated limestone cemented by barite is common 
(González-Sánchez, 2008). The tops of the mantos usually consist of mm-thick illite-rich layers. The contact between barite bodies and limestone is a narrow blanched alteration halo no bigger than $10 \mathrm{~cm}$ wide, probably dolomite. Barite aggregates consist of finegrained crystals (sucrose) and euhedral crystals, 1 to 10 cmlongwith no apparent preferred orientation. The remanent of textures and diagenetic characteristics inside of the ore body suggest a pseudomorphic replacement. Impurities in the barite aggregates are reminiscent of layering or pseudo-layering, such as changes in grain size as well as convoluted or folded surfaces and boudinage structures. Banded structures, akin to rhythmites, with alternating white and dark bands are common. Globular barite aggregates are interpreted as the result of the replacement of "chickenwire" anhydrite deposits, which are typically formed after diagenetic dehydration or compaction of evaporites (Fig. 3). Unlike, celestine deposits in the Cuatrociénegas area, the barite mantos atMúzquiz are devoid of vugs or other cavities and are thus essentially massive homogeneous bodies (Fig. 3). Organic matter type II and III (Martínez, et al., 2015), however, is common, especially in the dark bands of the rhythmites and interstitial to chicken-wire globular aggregates.

\section{Stable isotope analysis}

Representative samples for isotopic analysiswere separated by hand under the binocular microscope: 38 carbonate samples were selected for $\delta^{18} \mathrm{O}$ and $\delta^{13} \mathrm{C}$ analysis and 20 barite samples for $\delta^{18} \mathrm{O}$ and $\delta^{34} \mathrm{~S}$ analysis. Three types of carbonate samples were analyzed: 1) limestone fromthe Cupido Formation; 2)white calcite; and 3) grayish fetid calcite (rich in hydrocarbons). The latter two groups formed in mantos.

The $\delta^{18} \mathrm{O}$ and $\delta^{13} \mathrm{C}$ determinations in carbonates were conducted using a Finnigan MAT-253 mass spectrometer at the Instituto de Geología of the Universidad Nacional Autónoma deMexico. It is coupled with a dual sample introduction system, a Gas Bench with a GC Pal autosampler, and a thermostat. Analyzed $\mathrm{CO}_{2}$ was extracted from the samples using the analytical procedure described by Kinga et al. (2001) and Kinga and Landwehr (2002). Carbonate samples of $0.6 \mathrm{mg}$ were weighed and placed in container tubes at $25{ }^{\circ} \mathrm{C}$ in the Gas Bench. $99.995 \%$ pure helium was injected in the tubes for 10 min by means of a two-way needle in order to remove air from the tube, and then 10 drops of 
$100 \%$ pure orthophosphoric acid were injected with a tapped syringe in order to fully release all the carbonate as $\mathrm{CO}_{2}$. Carbon and oxygen isotope compositions are expressed in delta permil notation with respect to the Vienna Pee Dee Belemnite (VPDB) standard, and oxygen isotope composition is additionally expressed with respect to the Vienna Standard Mean Ocean Water (VSMOW) standard. The sulfates were combusted with $\mathrm{CuO}$ at 1000 ${ }^{\circ} \mathrm{C}$ to release $\mathrm{SO}_{2}$. The $\mathrm{SO}_{2}$ was analyzed in a VG SIRA 10 mass spectrometer. The analytical precision is better than $\pm 0.2 \%$. The sulfur isotope composition is expressed in delta permil notation with respect to the Vienna Canyon Diablo Troilite (VCDT) standard, and oxygen isotope composition is expressed with respect to the Vienna Standard Mean Ocean Water (VSMOW) standard. The analyses were carried out in the Department of Earth and Planetary Sciences at the University of New Mexico.

All the isotopic results from the analysis are shown in Table 1 . The $\delta^{34} \mathrm{~S}$ values obtained from barite range from $14.9 \%$ to $19.5 \%$ (mean 16.9\%o). Kesler and Jones (1981) reported rather similar $\delta 34 \mathrm{~S}$ values (between $14 \%$ and $17 \%$ ) for other barite mantos nearby. The $\delta 18$ OVSMOW values range from $17.1 \%$ to $20.7 \%$ o $\left(\delta^{18} \mathrm{O}_{\mathrm{VPDB}}=-13.35 \%\right.$ to $\left.-9.86 \%\right)$. The

$\delta^{13} \mathrm{C}$ values obtained from the host limestone range from $-0.01 \%$ to $0.11 \%$, from- $-1.5 \%$ to $-0.15 \%$ in white calcite, and from $-2.3 \%$ to $-1.41 \%$ in fetid calcite. The $\delta 13 \mathrm{C}$ values from the host limestone of the Cupido Formation are in accordance with those obtained by Lehmann et al. (1999) for the same formation $\left(0.15 \%\right.$ to $1.71 \%$ ). The $\delta^{18} \mathrm{O}_{\mathrm{VPDB}}$ values are similar for the three types of analyzed carbonate samples and range from $-10.04 \%$ to $-4.55 \%$ o $\left(\delta^{18} \mathrm{O}_{\text {vSMOW }}=20.56\right.$ to $26.22 \%$ ), (Fig. 6 ).

\section{Discussion}

The epigenetic stratabound carbonate-hosted low-temperature hydrothermal deposits in the Múzquiz area show diagnostic characteristics of Mississippi Valley-type deposits (Okita, 1992; Kisvaransayi et al., 1983; Sangster, 1983; Sverjensky, 1986). These barite deposits belong to the MVT province of northeastern Mexico (González-Sánchez et al., 2007, 2009) and occur in the central part of the graben portion of the Sabinas Basin north of the La Mula basement high. 
These MVT deposits are among those that formed deepest in the basin and the brines responsible for their formation starkly contrast with those that formed shallower deposits (González-Sánchez et al., 2007).

Whereas the mineralized fluids in shallower fluorite and Celestine deposits achieve very dilute $\mathrm{NaCl}$-dominated salinities, the $\mathrm{CaCl}_{2}$ brines consistently have a high salinity in theMúzquiz deposits. This feature is in accordance with the genetic scheme illustrated by González-Sánchez et al. $(2007,2009)$ for thewhole region and is attributed to either of two possible, non-mutually exclusive scenarios: 1) the progressive "loss" of salinity in mineralizing sedimentary brines as they ascended through the sedimentary pile and solutes were scavenged from the solution due to the formation of deep MVT deposits; and 2) a higher likeliness for brine dilution by meteoric water in shallow deposits than in deeper ones. Both possibilities may imply the entrainment of sedimentary brines out of different reservoirs.

Unlike most of the case deposits in González-Sánchez et al. (2009), fluid inclusions from the mantos at Múzquiz show relatively little variation in salinity. This feature is likely a result of the little to no interaction of basinal brines with meteoric waters with decreasing depth in the sedimentary pile in the Sabinas Basin. In other words, the deposits of the Múzquiz area stand out as the clearest example described in this region of sedimentary brines that did not experiencemuch interaction with meteoricwater during the formation of MVT-likemantos. The $\mathrm{C}$ and $\mathrm{O}$ isotopic compositions of hydrothermal minerals from the manto deposits at Múzquiz are in strong accordance with the composition of the host sedimentary rocks and further supports such an interpretation. The available sulfur isotope data suggest a sedimentary (evaporitic) source for sulfur which, in this case, would correspond to anhydrite deposits that formed after the dehydration of gypsum evaporites following compaction as revealed by the presence of "chicken-wire" structures replaced by barite.

\section{Conclusions}

The baritemining district of La Sierra de Santa Rosa is part of a large province of stratabound $\mathrm{Cu}, \mathrm{Pb}-\mathrm{Zn}$, barite and celestine deposits hosted at different stratigraphic levels 
in the Cretaceous Sabinas Basin. Stratabound deposits in the Sabinas Basin show a succession of: a) copper red beds; b) barite and barite- $\mathrm{Pb}+\mathrm{Zn}$ deposits; c) celestine horizons below fluorspar horizons; and d) the occasional presence of fluorite-uranium deposits.

The barite deposits are mantos consisting of high-grade barite with a stratabound and epigenetic character emplaced in the upper part of the Cupido Formation close to the contact with the La Peña Formation. Thesemantos showpseudo-morphism of sedimentary or diagenetic features, structures akin to banded rhythmites with alternating white and dark bands, and the presence of organic matter and "chicken-wire" structures replaced by barite.

Microthermometric analyses of barite showed homogenization temperatures which ranged between $59{ }^{\circ} \mathrm{C}$ and $155^{\circ} \mathrm{C}$ and temperatures of ice melting between $-26^{\circ} \mathrm{C}$ and -5 ${ }^{\circ} \mathrm{C}$. These results suggest that $\mathrm{CaCl}_{2}$-rich fluids largely dominated the solutes in the mineralizing brines with some minor contribution from meteoric waters. Results of stable isotopes of $\mathrm{S}, \mathrm{O}$, and $\mathrm{C}$ analyses in samples of barite, calcite and limestone suggest that the mineralizing fluids were dominantly basinal brines.

These results suggest that the mantos of the Sierra de Santa Rosa barite mining district were generated from the replacement of preexisting anhydrite horizons from the Cupido Formation.

Therefore, geological, microthermometric, and isotopic data obtained in this research suggest that the above deposits may be classified within the category of MVT-deposits.

\section{Conflict of interest}

The authors of the paper state no conflict of interestwith any person or institution.

Acknowledgments

This work was funded by projects \# IN101510-PAPIIT, \# IN101113-3-PAPIIT, and \# 155662 Conacyt. The authors thank mine engineers, David Requenes Nava and Enrique Aguirre, as well as the mine owner, Mr. Hugo Martínez, for kindly supplying geological information and permitting sampling. The stimulating reviews of the early manuscript 
versions by Macario Rocha-Rocha and Jessica Hobson clarified several potentially misleading parts, so to both we extend our thankfulness and gratitude. The authors are also grateful to the anonymous reviewers of this paper.

\section{References}

Alexandri, R.R., Martínez, V.A., 1986. Geología del Distrito Manganesífero de Molango. In: Hidalgo, E., Salas, G.P. (Eds.), Geología Económica de México. Fondo de Cultura Económica, México, pp. 401-408.

Bodnar, R.J., Vityk, M.O., 1994. Interpretation of microthermometric data for $\mathrm{NaCl}-\mathrm{H}_{2} \mathrm{O}$ fluid inclusions. In: De Vivo, B., Frezzotti, M.L. (Eds.), Fluid Inclusions in Minerals: Methods and Applications. Virginia Polytechnic Institute, State University, Blacksburg VA, USA, pp. 117-130.

Caballero-Martínez, J.A., Sánchez-Rojas, L.A., 2011. Distribución de los Yacimientos Estratoligados en el NE de México. In: Corona-Esquivel, R., Gómez-Caballero, J.A. (Eds.), Acta de Sesiones XXIX Convención Internacional de Minería Acapulco, Guerrero, Asociación de Ingenieros de Minas. Metalurgistas y Geólogos de México, pp. 29-35.

Camprubí, A., 2009. Major Metallogenic Provinces and Epochs of Mexico. SGA News. 25, pp. $1-20$.

Camprubí, A., 2013. Tectonic andmetallogenetic history of Mexico. Special Publication 17. Society of economic geologists, Inc., pp. 201-243.

Clark, K.F., De la Fuente, L., 1978. Distribution of mineralization in time and space in Chihuahua, Mexico. Mineral. Deposita 13, 27-49.

Crawford, M.L., 1981. Phase equilibria in aqueous fluid inclusions. In: Hollister, L.S., Crawford,M.L. (Eds.), Fluid Inclusions: Applications to Petrology, Mineralogical Association of Canada Short Course Handbook. 6, pp. 75-100.

Enos, P., 1974. Tamabra limestone of the Poza Rica trend, Cretaceous, México. In: Cook, H.E., Enos, P. (Eds.), Deep-Water Carbonate Environments, Society for Sedimentary Geology (SEPM) Special Publication. 25, pp. 273-314. 
Enos, P., 1983. Late Mesozoic paleogeography of México. In: Reynolds, M.W., Dolly, E.D. (Eds.), Mesozoic Paleogeography of West-Central United States: Rocky Mountain Section, Society for Sedimentary Geology (SEPM), pp. 133-157.

García-Alonso, D., Canet, C., González-Partida, E., Villanueva-Estrada, R.E., ProlLedesma, R.M., Alfonso, P., Caballero-Martínez, J.A., Lozano-Santa Cruz, R., 2011. The Cretaceous sediment-hosted copper deposits of San Marcos (Coahuila, Northeastern Mexico): an approach to ore-forming processes. J. S. Am. Earth Sci.31, $432-443$.

Goldhammer, R.K., Johnson, C.A., 2001. Middle Jurassic-Upper Cretaceous paleogeographic evolution and sequence-stratigraphic framework of the Northwest Gulf of México rim. In: Bartolini, R., Buffler, T., Cantú-Chapa, A. (Eds.), The Western Gulf of México Basin: Tectonics, Sedimentary Basins, and Petroleum Systems. AAPG Mem. 75, pp. 45-81.

González-Sánchez, F., Puente-Solís, R., González-Partida, E., Camprubí, A., 2007. Estratigrafía del noreste de México y su relación con los yacimientos estratoligados de fluorita, barita, celestina y Zn-Pb. Bol. Soc. Geol.Mex. 59, 43-62.

González-Sánchez, F., 2008, Caracterización y génesis de los yacimientos minerales estratoligados de celestina, barita, fluorita y plomo-zinc del Noreste de México. Unpublished Ph.D. Dissertation. Universidad Nacional Autónoma de México, Centro de Geociencias Juriquilla, p. 91.

González-Sánchez, F., Camprubí, A., González-Partida, E., Puente-Solís, R., Canet, C., Centeno-García, E., Atudorei, V., 2009. Regional stratigraphy and distribution of epigenetic stratabound celestine, fluorite, barite, and $\mathrm{Zn}-\mathrm{Pb}$ deposits in the MVT province of Northeastern Mexico. Mineral. Deposita 44, 343-361.

Humphrey, W.E., 1956. Tectonic framework of northeast Mexico. Gulf Coast Association of Geological Societies Transactions. 6, pp. 25-35.

Imlay, R.W., 1937. Geology of the middle part of the Sierra de Parras, Coahuila. Bull. Geol. Soc. Bull. 48, 587-630.

Imlay, R.W., 1940. Neocomian faunas of Northern Mexico. Geol. Soc. Am. Bull. 51, 117190. 
Kesler, S.E., Jones, L.M., 1981. Sulfur and strontium isotopic geochemistry of celestite, barite and gypsum from the Mesozoic basins of North Eastern Mexico. Chem. Geol.31, 211-224.

Kinga, M.R., Landwehr, J.M., Keybl, J., 2001. Measurement of $\delta^{13} \mathrm{C}$ and $\delta^{18} \mathrm{O}$ isotopic ratios of $\mathrm{CaCO}_{3}$ using a thermoquest finnigan gas bench II delta PLus XL continuous flow isotope ratio mass spectrometer with application to Devils Hole Core DH-11 calcite. U.S. Geol. Surv. Open-File Rep. 01-257.

Kinga, M.R., Landwehr, J.M., 2002. $\delta 13 \mathrm{C}$ and $\delta 18 \mathrm{O}$ isotopic composition of $\mathrm{CaCO}_{3}$ measured by continuous flow isotope ratio mass spectrometry statistical evaluation and verification by application to Devils Hole Core DH-11 calcite. Rapid Commun. Mass Spectrom. 16, 2102-2114.

Kisvaransayi, G., Grant, S.K., Pratt,W.P., Koening, J.W. (Eds.), 1983. International Conference on Mississippi Valley-Type Lead-Zinc Deposits, Proceedings Volume: Rolla, Missouri, E.U.A 603. University of Rolla.

Lehmann, C., Osleger, D.A., Montañez, I.P., Sliter,W., Arnaud-Vanneau, A., Banner, J., 1999. Evolution of Cupido and Coahuila carbonate platforms, Early Cretaceous, northeastern Mexico. Geol. Soc. Bull. 111, 1010-1029.

Martínez, L., Camacho, L.F., Piedad-Sánchez,N., González-Partida, E., Suárez-Ruiz, I., Enciso, J., 2015. Entorno diagenético en el Bloque Pirineo, Cuenca de Sabinas, México: Interacción agua- roca-hidrocarburo. Revista internacional de innovación e investigación tecnológica $3 \mathrm{~N}^{\circ} 13$.

Marton, G., Buffler, R.T., 1994. Jurassic reconstruction of the Gulf ofMéxico basin. Int. Geol. Rev. 36, 545-586.

Okita, P.M., 1992. Manganese carbonate mineralization in the Molango district, Mexico. Econ. Geol. 87, 1345-1366.

Padilla Y Sánchez, R.J., 1986. Post-Paleozoic tectonics of northeast Mexico and its role in the evolution of the Gulf of México. Geofis. Int. 25, 157-206.

Pindell, J., Kennan, L., 2001. In: Bartolini, R., Buffler, T., Cantú-Chapa, A. (Eds.), The Western Gulf of México Basin: Tectonics, Sedimentary Basins, and Petroleum Systems. 75, pp. 1-27. 
Puente-Solís, R., González-Partida, E., Tritlla, J., Levresse, G., 2005. In: Esquivel, R., Gómez-Caballero, J.A. (Eds.), Distribución de los depósitos estratoligados de Barita, Celestina, Fluorita, Plomo-Zinc en el Noreste de México. En Corona. XXVI Convención Nacional de Minería, México D.F., A.I.M.M.G.M, pp. 95-98.

Sangster, D.F., 1983. Mississippi Valley type deposits: a geological mélange. In: Kisvaransayi, G., Grant, S.K., Pratt, W.P., Koening, J.W. (Eds.), 1983, International Conference on Mississippi Valley-Type Lead-Zinc Deposits, Proceedings Volume: Rolla. E.U.A., University of Missouri-Rolla, Missouri, pp. 7-19.

Smith, I.C., 1981. Review of the geologic setting, stratigraphy and facies distribution of the Lower Cretaceous in northern México. In: Smith, C.I. (Ed.), Lower Cretaceous stratigraphy and structure, northern México, West Texas Geological Society Publication. 81/74, pp. 1-27.

Soto-Pineda, S., 1960, Reconocimiento geológico de los principales depósitos de fosforitas localizados en el estado de San Luis Potosí. Unpublished BSc dissertation, Escuela Superior de Ingeniería y Arquitectura, Instituto Politécnico Nacional, Distrito Federal, Mexico, p. 50.

Sverjensky, D.A., 1986. Genesis of valley-type lead-zinc deposits. Annu. Rev. Earth Planet. Sci. 14, 177-199.

Torres-Hernández, D., 2003, Comportamiento geológico y mineralógico de los mantos de barita del Potrero y El Palmito en el distrito minero de Múzquiz, Coah. Unpublished BSc dissertation, Universidad Autónoma de Nuevo León, Linares, Nuevo León, Mexico, p. 110.

Vivanco-Flores, E., 1976, Estudio geológico-económico de roca fosfórica en la sierras de Garambullo y Fraile, mpio. De Saltillo, Coah. Unpublished BSc dissertation, Escuela Superior de Ingeniería y Arquitectura, Instituto Politécnico Nacional, Distrito Federal, Mexico, p. 58.

Wilson, J.L., 1975. Carbonate Facies in Geologic History. Springer-Verlag, New York 417 p. Zantop, H., 1978. Geologic setting and genesis of iron and manganese oxides in the San Francisco manganese deposit, Jalisco, México. Econ. Geol. 73, 1137-1149. 


\section{FIGURE CAPTIONS}

Figure 1. Distribution of stratabound deposits in northeastern Mexico, and southern United States showing the main manifestations of mineralization linked to uranium, lead-zinc, barite, celestine, fluorite and copper in red-beds. Slightly modified from (Camprubí, 2013).

Figure 2. Geological map of Sierra de Santa Rosa Mining district showing regional and local geology, stratigraphic column and mineralized horizons within the Cupido Formation (KbapCz). Modified from (González-Sánchez et al., 2007).

Figure 3. Representative example of barite ore body textures. A: Globular aggregates (replacement of "chicken-wire" primary anhydrite deposits). B: Banded structures (rhythmites, alternating white and dark bands).

Figure 4. Typical microphotographs of fluid inclusions on barite. A: Fluid inclusions with constant liquidvapor ratios, B: Fluid inclusions with evidences of leakage and necking showing diverse liquid-vapor ratios.

Figure 5. Diagrams showing the relation between temperature of homogenization $\left(\mathrm{Th}{ }^{\circ} \mathrm{C}\right)$ and temperature of final fusion $\left(\mathrm{Tmi}{ }^{\circ} \mathrm{C}\right)$ in calcite and barite from the different layers of the area in the Sierra de Santa Rosamining district. A: Uppermanto B: Lowermanto. Clusters of both, barite and calcite minerals are separated by lines of the same color. From González-Sánchez et al. (2007).

Figure 6. Graphic of $\delta 18 \mathrm{OVPDB}$ vs $\delta 13 \mathrm{CVPDB}$ for the Sierra de Santa Rosa baritemining district. Data from both mantos, upper and lower are included. Other trends of isotope evolution have been plotted as a reference: burial diagenesis, the Cupido Formation carbonates and the meteoric waters diagenesis. Modified from González-Sánchez et al. (2007). 
Fig. 1

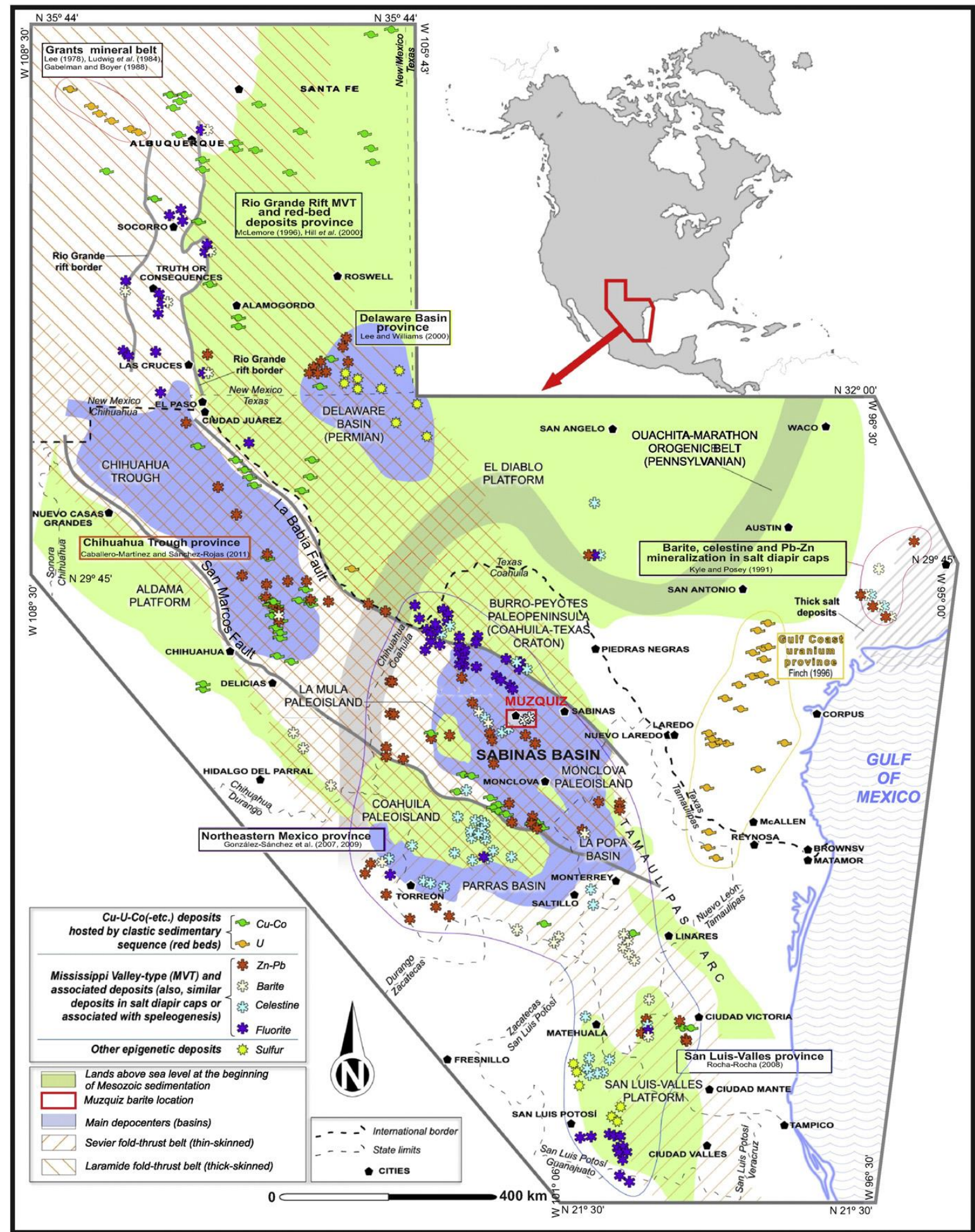


Fig. 2

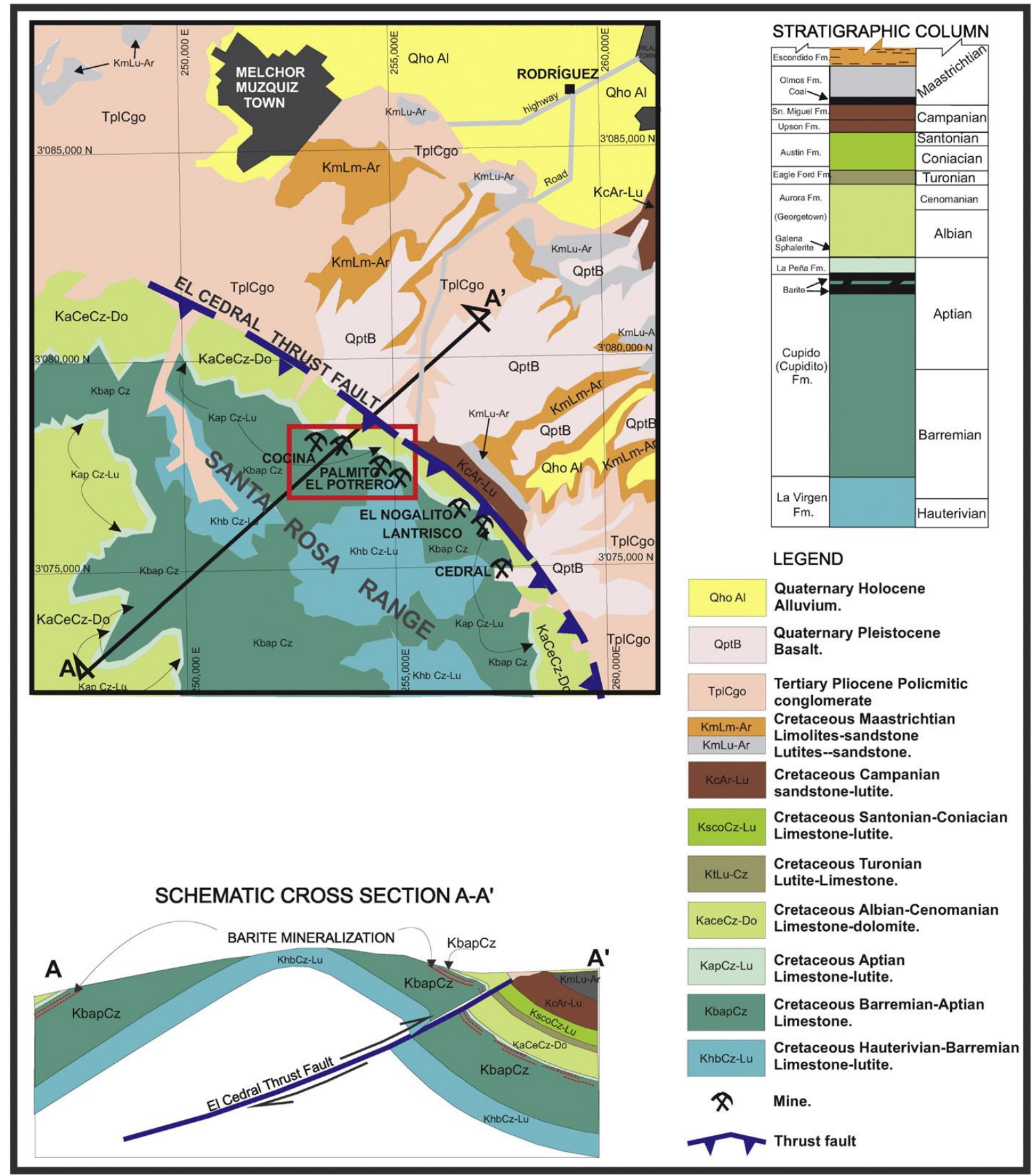


Fig. 3

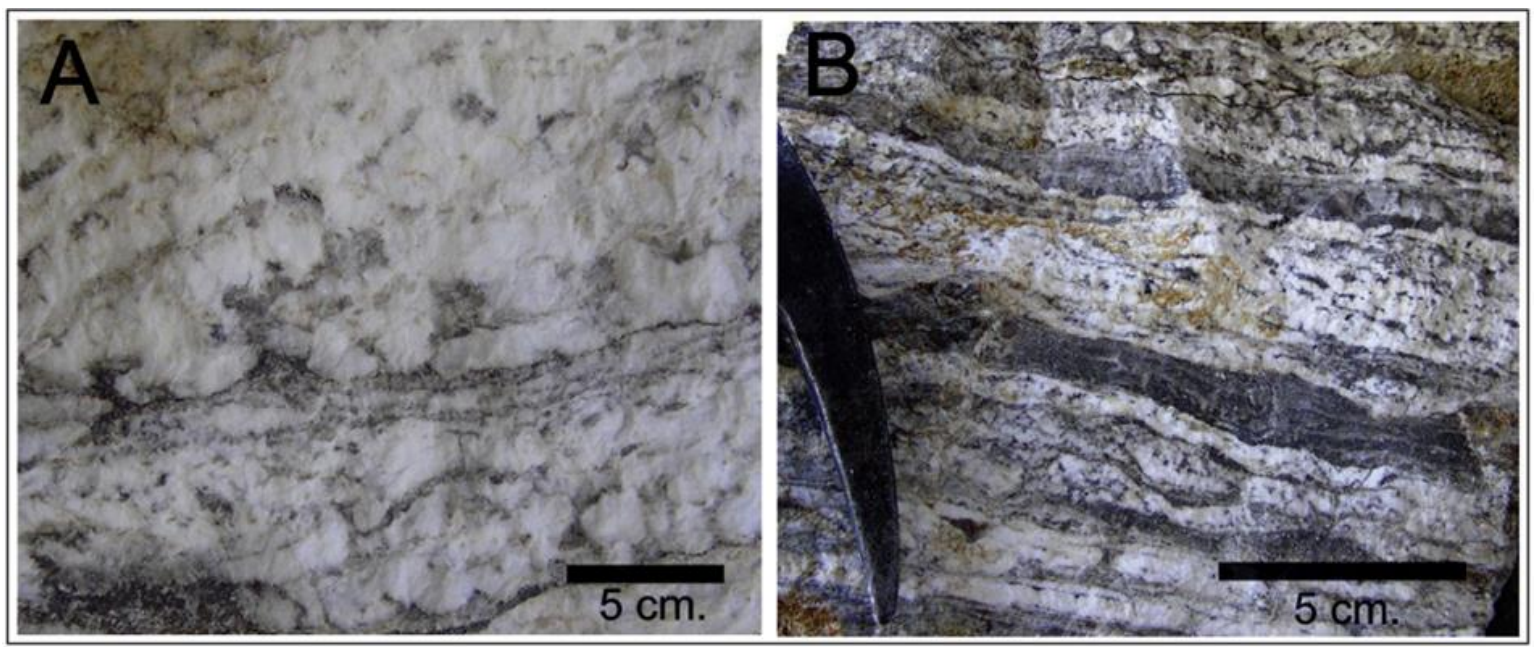

Fig 4

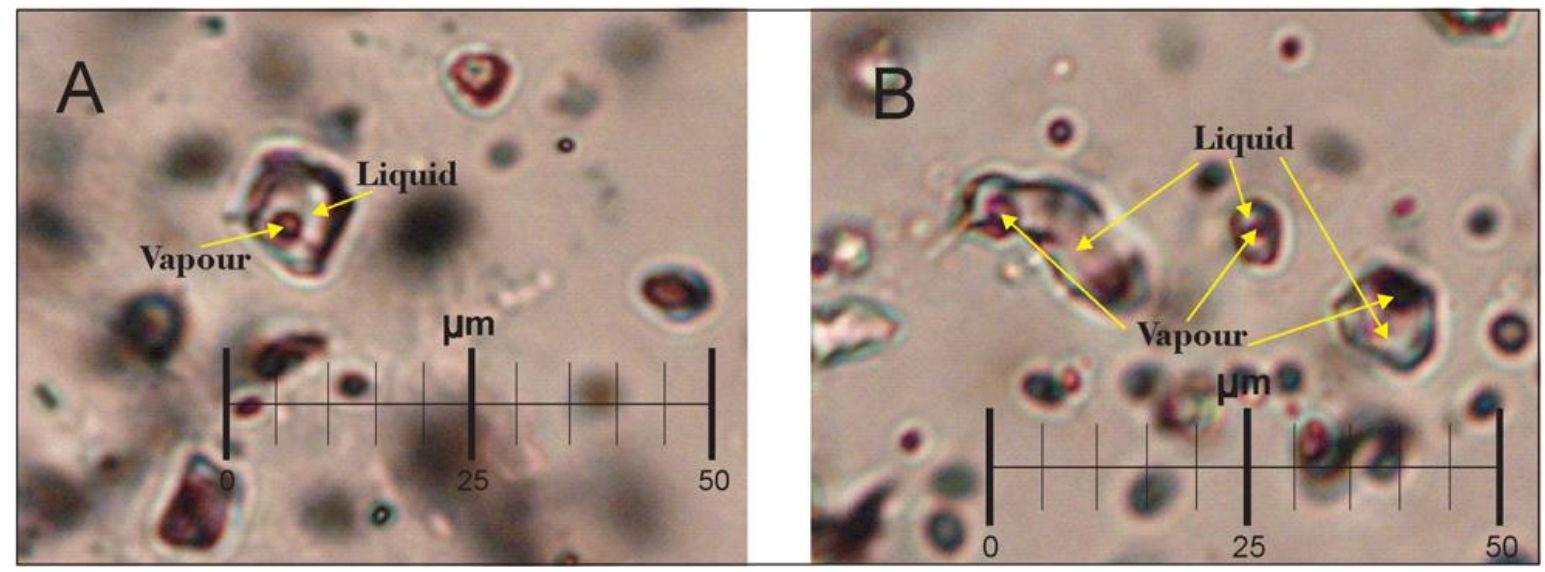


Fig. 5
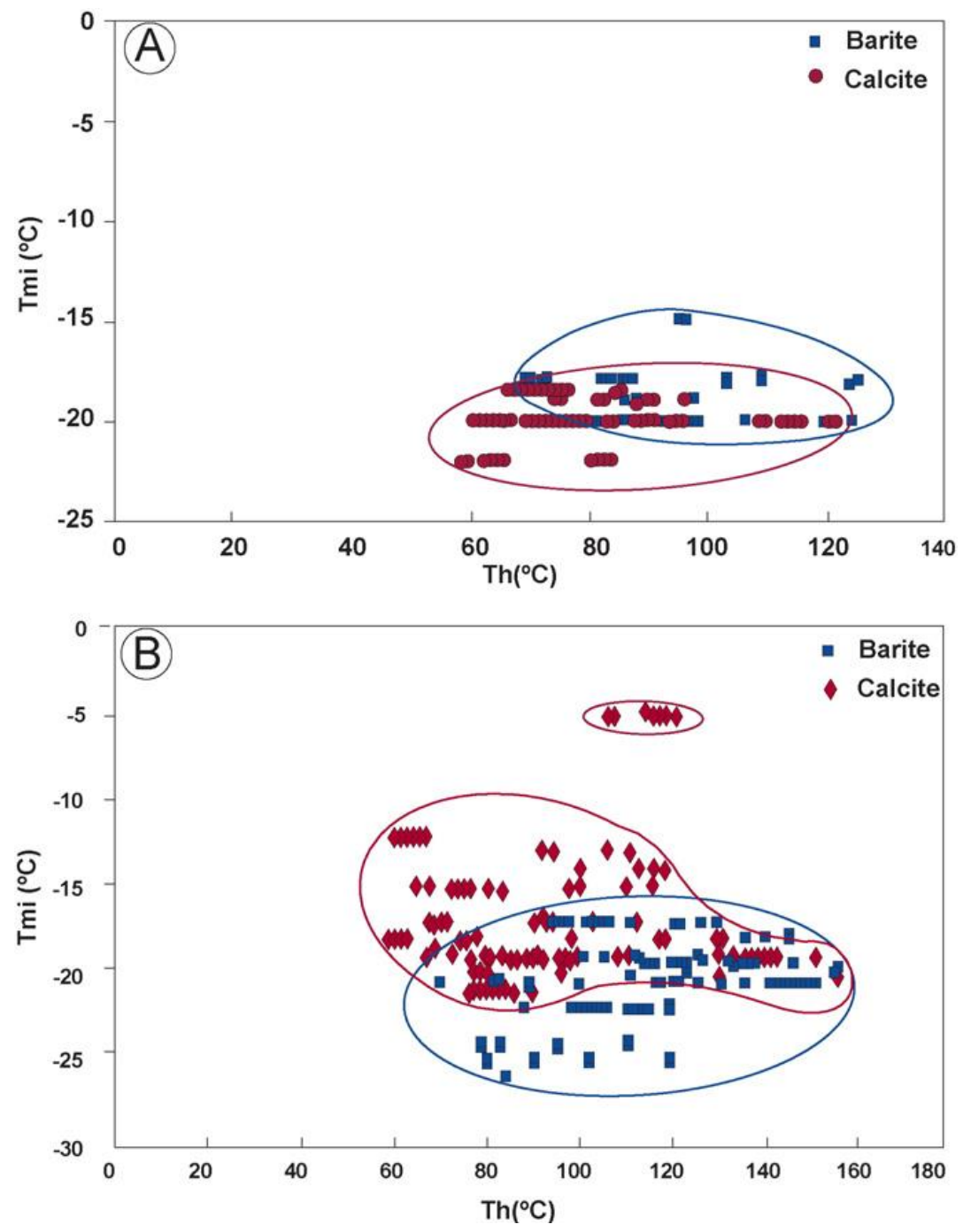
Fig. 6

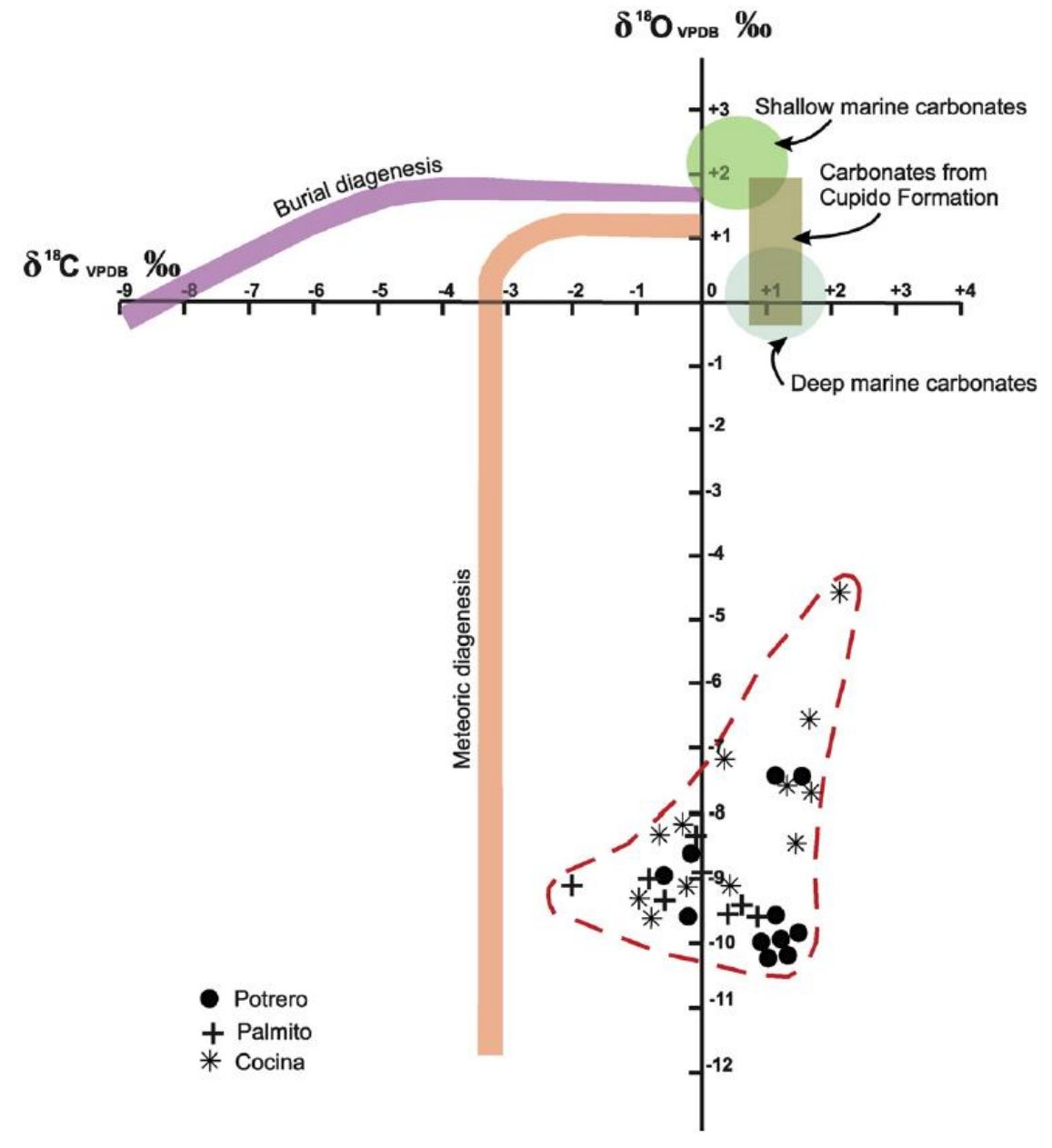


Table 1

Results of fluid inclusions and isotopic geochemistry studies from Sierra de Santa Rosa barite mining district, Coahuila, Mexico.

\begin{tabular}{|c|c|c|c|c|c|c|c|c|c|c|c|}
\hline \multirow[t]{3}{*}{ Place } & \multirow[t]{3}{*}{ Material } & \multirow[t]{3}{*}{ Key } & \multicolumn{9}{|l|}{ Results } \\
\hline & & & \multicolumn{5}{|c|}{ Fluid inclusions } & \multicolumn{4}{|c|}{ Stable sotopes } \\
\hline & & & $\begin{array}{l}\text { Range Th } \\
\left({ }^{\circ} \mathrm{C}\right)\end{array}$ & $\begin{array}{l}\text { Th Av } \\
\left({ }^{\circ} \mathrm{C}\right)\end{array}$ & $\begin{array}{l}\text { Range Tmi } \\
\left({ }^{\circ} \mathrm{C}\right)\end{array}$ & $\begin{array}{l}\text { Tmi Av. } \\
\left({ }^{\circ} \mathrm{C}\right)\end{array}$ & $\begin{array}{l}\text { Salinity } \\
\text { wt.\% } \mathrm{NaCl} \\
\text { equiv. }\end{array}$ & $\begin{array}{l}\delta 13 C \\
\text { VPDB } \\
(\%) \\
\end{array}$ & $\begin{array}{l}\delta^{18} \mathrm{O} \\
\mathrm{VPDB} \\
(\%) \\
\end{array}$ & $\begin{array}{l}\delta^{18} \mathrm{O} \\
\text { VSMOW } \\
(\%)\end{array}$ & $\begin{array}{l}\delta^{34} \mathrm{~S} \\
\text { VCDT } \\
(\%) \\
\end{array}$ \\
\hline Potrero & Calcite & MS-1 & & & & & & -0.28 & -9.41 & 21.21 & \\
\hline Potrero & Calcite & MS-2 & 60 to 89 & 73.5 & -20 to -22 & -20.7 & 22.9 & 1.02 & -9.52 & 21.10 & \\
\hline Potrero & Barite & MS-3 & & & & & & & & & 16.7 \\
\hline Potrero & Calcite & MS-4 & & & & & & 1.07 & -9.99 & 20.61 & \\
\hline Potrero & Barite & MS-5 & & & & & & & & & 15.8 \\
\hline Potrero & Calcite & MS-6 & & & & & & 1.22 & -9.74 & 20.87 & \\
\hline Potrero & Calcite & MS-7 & 75 to 122 & 103.7 & -19 to -20 & -19.5 & 22.1 & -0.61 & -8.77 & 21.87 & \\
\hline Potrero & Barite & MS- 8,9 & 86 to 98 & 91.71 & -15 to -20 & -18.2 & 21.1 & & & & 20.0 \\
\hline Potrero & Limestone (gray) & MS-10 & & & & & & 1.38 & -7.43 & 23.25 & \\
\hline Potrero & Limestone (dark) & MS-11 & & & & & & 1.61 & -7.72 & 22.95 & \\
\hline Potrero & Calcite & MS-12 & 63 to 110 & 77.86 & -20 & -20 & 22.4 & -1.28 & -8.61 & 22.03 & \\
\hline Potrero & Barite & MS-13 & 81 to 125 & 108.1 & -20 & -20 & 22.4 & & & & 21.2 \\
\hline Potrero & Calcite & MS-14 & & & & & & 1.17 & -9.76 & 20.85 & \\
\hline Potrero & Barite & MS-15 & & & & & & & & & 21.1 \\
\hline Potrero & Barite & MS-16 & & & & & & & & & 20.3 \\
\hline Potrero & Calcite & MS-17 & 68 to 85 & 72.23 & -18.5 & -18.5 & 21.3 & 1.04 & -9.81 & 20.80 & \\
\hline Potrero & Barite & MS-18 & 80 to 96 & 93.67 & -20 & -20 & 22.4 & & & & 19.3 \\
\hline Potrero & Calcite & MS-19 & & & & & & 1.17 & -10.04 & 20.56 & \\
\hline Potrero & Barite & MS-20 & & & & & & & & & 20.0 \\
\hline Potrero & Limestone & MS-21 & & & & & & 0.26 & -8.55 & 22.10 & \\
\hline Palmito & Barite & MIP-1 & 87 to 119 & 100.8 & -20 to -25 & -22.7 & 26.4 & & & & 16.2 \\
\hline Palmito & Calcite & MIP-1 & 98 to 150 & 131.2 & -19 & -19 & 21.7 & 0.08 & -8.74 & 21.90 & \\
\hline Palmito & Calcite & MIP-2 & & & & & & 0.56 & -9.34 & 21.28 & \\
\hline Palmito & Barite & MIP-3 & & & & & & & & & 15.8 \\
\hline Palmito & Calcite & MIP-3 & 76 to 90 & 82.76 & -21 & -21 & 23.1 & -0.66 & -9.38 & 21.24 & \\
\hline Palmito & Barite & MIP-4 & & & & & & & & & 14.5 \\
\hline Palmito & Calcite & MIP-4 & & & & & & 0.71 & -9.43 & 21.19 & \\
\hline Palmito & Barite & MIP-5 & & & & & & & & & 15.4 \\
\hline Palmito & Barite & MIP-6 & & & & & & & & & \\
\hline Palmito & Limestone & MIP-6 & & & & & & -0.14 & -8.45 & 22.20 & \\
\hline Palmito & Calcite & MIP-7 & & & & & & -2.33 & -8.89 & 21.75 & \\
\hline Palmito & Barite & MIP-8 & 70 to 150 & 126.8 & -20.3 & -20.3 & 22.6 & & & & 17.0 \\
\hline Palmito & Calcite & MIP-9 & & & & & & -0.69 & -9.26 & 21.36 & \\
\hline Palmito & Limestone & MIP-9 & & & & & & -0.83 & -8.78 & 21.86 & \\
\hline Cocina & Calcite & MIC-1 & & & & & & -0.18 & -8.25 & 22.40 & \\
\hline Cocina & Limestone & MIC-1 & & & & & & 0.17 & -6.90 & 23.80 & \\
\hline Cocina & Limestone & MIC-2 & & & & & & 2.25 & -4.55 & 26.22 & \\
\hline Cocina & Barite & MIC-3 & 79 to 110 & 88.17 & -24 to -26 & -24.3 & 26.45 & & & & 20.2 \\
\hline Cocina & Barite & MIC-4 & 110 to 155 & 123.3 & -19.3 & -19.3 & 21.9 & & & & 12.9 \\
\hline Cocina & Calcite & MIC-4 & 65 to 115 & 82.3 & -15 to -18.7 & -15.6 & 19.1 & -1.23 & -9.23 & 21.39 & \\
\hline Cocina & Barite & MIC-5 & & & & & & & & & 11.8 \\
\hline Cocina & Calcite & MIC-5 & 67 to 110 & 88 & -19 & -19 & 21.7 & 0.32 & -9.14 & 21.49 & \\
\hline Cocina & Barite & MIC-6 & & & & & & & & & 13.3 \\
\hline Cocina & Calcite & MIC-6 & 90 to 120 & 104.3 & -5 to -17 & -10.7 & 14.7 & -1.33 & -9.26 & 21.36 & \\
\hline Cocina & Limestone & MIC-6 & & & & & & -1.27 & -9.11 & 21.52 & \\
\hline Cocina & Calcite & MIC-7 & & & & & & -0.22 & -8.15 & 22.51 & \\
\hline Cocina & Limestone & MIC-7 & & & & & & 0.68 & -8.29 & 22.36 & \\
\hline Cocina & Calcite & MIC-8 & 75 to 135 & 103.2 & -14 to -19.9 & -17.9 & 20.9 & -0.56 & -9.14 & 21.49 & \\
\hline Cocina & Barite & MIC-9 & 98 to 145 & 121.7 & -17 to -20 & -18.2 & 21.1 & & & & 19.6 \\
\hline Cocina & Calcite & MIC-9 & 49 to 75 & 67.58 & -15 to -18 & -16.3 & 19.7 & 0.37 & -9.53 & 21.09 & \\
\hline Cocina & Calcite & MIC-10 & 60 to 66 & 62.75 & -12 & -12 & 16 & -2.19 & -8.50 & 22.15 & \\
\hline Cocina & Limestone & MIC-10 & & & & & & -0.69 & -8.70 & 21.94 & \\
\hline Cocina & Barite & MIC-11 & 96 to 130 & 104 & -17 to -19 & -18.22 & 21.1 & & & & 16.3 \\
\hline Cocina & Limestone & MIC-11 & & & & & & -1.44 & -9.82 & 20.79 & \\
\hline Cocina & Calcite & MIC-12 & & & & & & 1.35 & -7.38 & 23.30 & \\
\hline Cocina & Limestone & MIC-12 & & & & & & 1.59 & -7.34 & 23.34 & \\
\hline Cocina & Calcite & MIC-13 & & & & & & 1.56 & -8.43 & 22.22 & \\
\hline Cocina & Limestone & MIC-13 & & & & & & 1.76 & -6.50 & 24.21 & \\
\hline
\end{tabular}

$\mathrm{Th}=$ Homogenization temperatures; $\mathrm{Tmi}=$ Melting ice temperatures. 